\title{
A CRITIQUE OF THE SOCIOLOGICAL APPROACH TO CRIME AND CORRECTION
}

\author{
Frank E. Hartung*
}

I

It is difficult for a sociologist to write a critique of his own discipline's approach to crime and correction. First, it is evident to all who know the field that sociology is not a unitary discipline. It can, thus, neither be praised nor condemned as a whole, and it is necessary to specify what kind of sociology is being lauded or derogated. Second, sociologists seem to agree on hardly anything except loyalty to their common field, and there is a widespread belief among them that many of them are actually subverting sociology. It will be seen that criminologists are so free in destroying and rejecting each other's theories and hypotheses that criminology must appear nihilistic to the outsider. Third, there is dispute concerning both the legitimate limits of the discipline and what common sociological principles are. As to its limits, some sociologists have surrendered to the imperialistic claims of biology, psychiatry, psychoanalysis, and psychology. In so doing, they have deprived themselves of any logical basis for their own intellectual and professional existence. Other sociologists, it will be seen, have rejected the claims of other disciplines to criminology and have asserted their own imperialism. In so doing, they have finally joined battle with psychiatry, which, under the aegis of an irrationalist psychology, laid claim in the fourth quarter of the nineteenth century to the entire domain of human behavior and society. The two main criminological contenders today are the irrationalist psychology of psychiatry and the social psychology of sociology.

It would be difficult, and likely impossible, to obtain agreement among the members of the American Sociological Society to any proposed set of sociological principles or propositions. This returns us to the first point-namely, that sociology is not a monolithic structure. In I929, Read Bain referred to the attempt by Albion Small, in 1907 , to state the agreements then existing among sociologists. There was considerable disagreement at that time with Small's points. Bain said that he would not accept more than four or five of Small's twenty points. In presenting his points in 1929, Bain said that he had "little faith" that even a majority of sociologists would agree with them. The amount of agreement with them in twenty years, he continued, "may well be less than my present agreement with Small." $\mathrm{He}$ was correct.

*A.B. x933, Wayne State University; M.A. x934, Ph.D. x949, University of Michigan. Associate Professor of Sociology and Anthropology, Wayne State University. Member, Michigan Corrections Advisory Commission, 1951-54; Chairman, Group for the Study of Social Organization of Correctional Institutions, Social Science Research Council, 1955-58; Member, Moran Memorial Institute on Crime and Delinquency, St. Lawrence University, 1957. Contributor to sociological and penological publications.

${ }^{1}$ Bain, Trends in American Sociolgical Theory, in George A. Lundberg, Read Bain, \& Nels Anderson (Eds.), Trends in American Sociologx ios (r929). 
It is necessary, in order to make the rationale of this critique evident, to formulate some of the sociological principles on which it is based. This will help to indicate the kind of sociology that characterizes this study, as well as something of the viewpoint from which the studies cited in this article are evaluated. There is no claim that these nine propositions would receive the assent of a simple majority of sociologists; they do, however, represent its historically-dominant viewpoint:

r. Society and culture are real and have produced habits of action, thought, and feeling which form a body of phenomena with principles of its own.

2. The cultural habits of a society pre-exist with respect to its individual members, so that the individual social behaviors must be referred to the cultural forms.

3. All knowledge is inferential and symbolic (linguistic), rather than intuitive.

4. The self is without residue a product of sociocultural experience.

5. Human observation (perception) is a cognitive process in which the individual first interprets and then acts.

6. Sociocultural values and habits are primary in human conduct.

7. The psychoanalytic unconscious is a postulate, and not a psychological element.

8. Symbolic behavior is purposive.

9. The individual develops an organization of roles in a process of symbolic communication.

II

The above nine propositions are by no means the only ones on which this critique is based, but they are all relevant to the following evaluation of sociological works. They are drawn from the social-psychological school known as symbolic interaction. Even though it would not, perhaps, be possible to muster a simple majority in favor of these propositions, there are occasions on which sociologists can unite-and this exemplifies the sociological principle that attacks from an external enemy tend to unite an in-group that is at conflict within itself.

An instance of partial sociological unity was produced by the publication of the Gluecks' Unraveling Juvenile Delinquency. ${ }^{2}$ All but one of the published sociological reviews or articles read by this writer were more or less highly critical. Ernest W. Burgess stated that its two outstanding limitations are: ${ }^{3}$

( $\mathrm{r}$ ) the failure on two crucial points in matching the delinquents and the nondelinquents and (2) the one-sided interpretation of the findings.

Burgess accused the Gluecks of the failure to utilize the most significant of their findings, which show the gang membership of the delinquents and the absence of such affiliation by the nondelinquents, and of looking for the basic explanation of delinquency in inherited tendencies and in a personality structure that is allegedly formed before the child enters school.

Clinard stated that their work is deficient in the knowledge and application of

2 Sheldon \& Eleanor T. Glueck, Unraveling Delinquency (1950).

'Burgess, Book Review, Fed. Prob., March 1951, pp. 52, 53. 
contemporary social-psychological theory concerning human behavior. He indicated the fact that the Gluecks ignored their own finding that almost all of the delinquents were members of gangs and that only three of the nondelinquents belonged to gangs. He also called attention to the Gluecks' possible inversion of cause and effect: are delinquents aggressive because they are delinquent, or are they delinquents because they are aggressive? ${ }^{4}$

Some students criticized the Gluecks for their use of the as yet unvalidated Rorschach technique. Lois-ellin Greene Datta disagreed with their use of this technique, but upon a different ground. Mrs. Datta's position is that the Rorschach test has been validated as an index of personality structure and content. Her objection to its use by the Gluecks is that its ${ }^{5}$

. . . isolation from other subject-variables in the Gluecks' research seemed more designed to test the Rorschach's validity than to discover variations between delinquent and nondelinquent boys.... [Mrs. Datta's] objection is emphatically to the patchwork statistics imposed upon both Rorschach and Wechsler-Bellevue techniques. The Rorschach especially is a holistic technique: the entire pattern of responses is what is significant, not one response factor alone. There is no experimental, let alone logical, basis for [computing] correlations between isolated factors, e.g., "c" and " $\mathrm{f}$ " of Rorschachs. This particularistic factor splitting, so far as ... [Mrs. Datta] is concerned, destroys any significance which the Rorschachs might have had in this [Unraveling Juvenile Delinquency] study.

Attention has briefly been called to three points by Hartung, in a review of Physique and Delinquency, ${ }^{6}$ the Gluecks' latest book to be based upon material gathered for and presented in Unraveling Juvenile Delinquency. First, their statistical manipulations in Physique and Delinquency are questionable. These are presented in 109 tables and were performed in an effort to ascertain which traits and factors supposedly exert a significant differential influence on the delinquency of four bodily types (mesomorphic, endomorphic, ectomorphic, and balanced), and which do not. None of the rog tables deals with the entire sample of delinquents and nondelinquents. There are at least forty-six tables in which the number of delinquents, or controls, or both, is less than 100. In table fifty-nine, for example, the number of nondelinquents is twenty-seven, with the four types having, respectively, four, fifteen, eight, and zero representatives! Second, the Gluecks repeat explicitly one reason why criminologists were skeptical of their claim in $195^{\circ}$ to be able to predict delinquency as early as the sixth year-namely, proof is lacking of the permanence and immutability of the somatotype. ${ }^{7}$ Third, the Gluecks ignore a fundamental social-psychological problem-namely, personality is so undeveloped at the age of six years that it is not possible to predict, better than chance, what later choice of models for behavior will be made by a boy.

\footnotetext{
'Clinard, Book Review, Fed. Prob., March 1953, p. 50; The Sociology of Delinquency and Crime, in Joseph B. Gittler (ED.), Review of a Decade 480 (1957).

${ }^{5}$ Lois-ellin Greene Datra, Sociologtcal Theory in Contemporary American Sociology 28 (unpublished thesis in University of West Virginia Library 1955).

${ }^{6}$ Hartung, Book Review, 48 J. Crm. L., C. \& P.S. 638 (1958).

${ }^{7}$ Sheldon \& Eleanor T. Glueck, Physigue and Delinquency 256 (1956).
} 
In an interesting. analysis of the Gluecks' data, Reckless rearranged the 107 factors that the Gluecks employed in order to ascertain which factors are statistically associated with delinquency and nondelinquency. ${ }^{8} \mathrm{He}$ arranged his table into three groups: situational, individual, and intermediate factors. Reckless' table showed that the statistical association of the situational factors is much greater than that of individual factors to delinquency and nondelinquency. This finding is at considerable variance with the Gluecks' interpretation of their data, an interpretation that they incorporated into their "causal law." Reckless' analysis, of course, directly called into question the validity of that "causal law." Reckless also called attention, as did Burgess and Clinard, to the fact that the Gluecks' data on gang membership for delinquents and its absence among nondelinquents, tends to confirm Sutherland's theory of differential association, of which Sheldon Glueck has been an archopponent. ${ }^{9}$

Reiss analyzed, among other things, the theory and design of Unraveling Juvenile Delinquency and found that the Gluecks' conclusions were not the result of a systematic attempt to test a series of hypotheses about the etiology of delinquency. Since their study was eclectic and not guided by any theory, their interpretations of their findings were necessarily ex post facto. Reiss also showed that the two groups in the study were poorly matched on neighborhood and environmental factors, and that the study largely ignored the influence of primary groups in guiding behavior and in enforcing conformity to sets of norms. ${ }^{10}$

Rubin found illusions in the plan of Unraveling Iuvenile Delinquency in its method, its findings, and the interpretation of its data. He found two outstanding facts to emerge from the study: First, although the Gluecks sought steadfastly to eliminate environmental influences, the great influence of social causation proved to be irrepressible in their data. Second, institutionalized children differ from children who have not been institutionalized. ${ }^{11}$

Sellin concluded that the Gluecks' conception of cultural conflict was inadequate. ${ }^{12}$ Taft found the work inadequate in several respects: First, the Gluecks did not show-as they claimed-that family tensions are the deepest causes of delinquency. Second, the delinquents and nondelinquents were paired in the neighborhood by physical proximity only. Because of this neglect of social influences in the neighborhood, it is not possible to accept the Gluecks' claim that the two groups in the study were actually paired by identical social influences of the neighborhood.13

Vold has called attention to the very great amount of overlapping between the de-

${ }^{8}$ Walter C. Reckless, The Crime Problem 75 (2d ed. 1955).

${ }^{\circ}$ Id. at 77 .

${ }^{10}$ Reiss, Unraveling luvenile Delinquency, II. An Appraisal of the Research Methods, 57 AM. J. SocroloGy II5 (I95I).

${ }^{11}$ Rubin, Unraveling luvenile Delinquency, 1. Illusions in a Research Project Using Matched Pairs, id. at $107, \mathrm{Ir}_{3}$.

${ }^{19}$ Sellin, Book Review, 41 J. CRIM. L. \& CrIMIvolocy 732. 738 (1951).

${ }^{13}$ Taft, Implication of the Glueck Methodology for Criminal Research, 42 J. Crim. L., C. \& P.S 300 (x951). 
linquents and nondelinquents in respect to many of the factors considered by the Gluecks. The latters' data are far from revealing any clearly-delineated differences between the personalities of delinquents and nondelinquents. When the two groups are compared as to the extent and type of mental pathology as- summarized in the psychiatric diagnoses based on Rorschach data, the similarities of the two groups are very striking. There is comparatively little indication of differences. This is also true of the ten "traits of basic character structure" listed by the Gluecks. For anyone who wishes to develop a logical theory of personality or of "individual factors" as being basic in the causation of crime or delinquency, these similarities are likely to be confusing. The "deviant" personality, Vold thus showed, is limited strictly to relatively obscure statistical findings in terms of probability; otherwise, delinquents and nondelinquents are much more alike than different. ${ }^{14}$

Edwin $\mathrm{H}$. Sutherland may be said to have entered the lists against Unraveling Juvenile Delinquency in advance. He began his career as a criminologist largely in the role of a critic. ${ }^{15}$ By the unhappy chance of his untimely death, his last published writing was a critical appraisal of William H. Sheldon's Varieties of Delinquent Youth. ${ }^{16}$ His critiques of Hooton, Sheldon, and the Gluecks indicate that his most trenchant evaluations were directed at projects involving large expenditures of time, money, and energy; and the larger the claims made, the more severe his remarks, if he believed the basic position to be unsound. In reviewing the Gluecks' Later Criminal Careers, he treated severely their biological theory of "aging" or "maturation" as being the process that changed the criminal into a lawful person. ${ }^{17}$ Although he undertook his usual minute examination of the statistical procedures (which he found quite wanting), his attention was directed to the portion of the Gluecks' study that dealt with mental abnormality. His analysis reveals part of the basis for the sociological conclusion that crime cannot be explained by traits of the individual, as well as some of the reasons for the dissatisfaction with and distrust of psychiatric concepts. Concerning the Gluecks' statistics of mental abnormality, he wrote: ${ }^{18}$

When [these] data and methods are examined, they are found to be completely untrustworthy. This is the most unreliable part of the book.

Sutherland said of Hooton's two criminological works that the evidence that

24 George B. Vold, Theoretical Criminology 128-29, 130 (1958). An English critic said: "If they [the Gluecks] had studied the neighborhood as an entity they would have had to discard the highly developed techniques they had developed for the observation and assessment of series of individuals. But they preferred to shape their problem to the mode required by their instruments-like the ear, nose and throat surgeons of yesterday." Mack, Book Review, 3 BrIT. J. Deline. 304 (1953).

${ }^{16}$ Ale ert K. Cohen, Alfred R. Lindessith, \& Kari F. Schuessler (Eds.), The Sutheriand PAPERS 270 (1956).

${ }^{20}$ Sutherland, A Critique of Sheldon's "Varieties of Delinquent Youth," I6 AMr. Socrolocical REv. Io (195I).

${ }^{17}$ Sutherland, Book Review, 5 I HARv. L. REv. I84 (1937). A previously unpublished appraisal which is an extension of the above review is to be found in Cohen, Lindesmith, AND Schuessier, op. cit. stipra note 15 , at $29 \mathrm{I}$.

${ }^{18}$ Cohen, Lindesmith, \& Schuessler, op. cit. stipra note 15 , at $30 \mathrm{r}$. 
Hooton presented proved nothing at all for the latter's claim that criminals are physically different from lawful persons. ${ }^{19}$ Sutherland, in the opinion of some students, was rather lenient in dealing with Sheldon's constitutional psychology. He wrote of it as follows: ${ }^{20}$

The futility of this study in constitutional psychology should have been obvious in advance from the previous failures of analogous studies. Sheldon adds himself to the list of Lombroso, Kretschmer, Hooton and others who have attempted to demonstrate a physical difference between criminals and noncriminals. Unfortunately, the administrators of research funds can be seduced into wasting many hundreds of thousands of dollars on. such projects even after the results of previous studies have been repeatedly shown not to be worth a nickel.

The Gluecks, in Unraveling Juvenile Delinquency, drew heavily upon Hooton, and their work was praised by him. They also utilized Sheldon's constitutional psychology, both its concepts and techniques. Their latest book, Physique and Delinquency, is devoted largely to presenting their Sheldonian data. Sutherland would, therefore, have been interested in the following editorial note in the British Tournal of Delinquency: ${ }^{21}$

We hear from Harvard University that the Ford Foundation has made a grant of \$200,000 to the Harvard Law School in support of the researches into the causes and treatment of juvenile delinquency conducted under the direction of Professor and Mrs. Glueck. This grant, it is stated, "will enable the Gluecks to accelerate the development and validation of their diagnostic tests designed to reveal early tendencies to delinquency in children."

The above discussion has two constructive purposes; it is not intended merely to illustrate that some sociologists will take issue with those who call into question the legitimate existence of their discipline. Rather, first, it tends to confirm the charge sometimes made against sociologists that they are more skillful in destroying other people's theories, researches, and conclusions than they are at developing their own. It will be seen below that they often deal in no more charitable a fashion with those in their own field. Second, the critical type of discussion listed above is at least just as constructive as it is destructive. This positive aspect of criticism is usually not appreciated. A reading of the sociological discussions of Unraveling Tuvenile Delinquency will reveal that they make substantive contributions to problems of methodology, the planning of research, the utilization of previous theory and knowledge, and to the development of a unifying or integrative theory of criminology, as well as having implications for logically establishing the limits of sociology and criminology. The last point is another that will be discussed below. In addition,

${ }^{10}$ See Sutherland, Book Review, 29 J. Crm. L. \& CRImrnology 911 (1939). This review is reprinted in CoHEN, LiNDESMITH, \& SCHUEsSLER, op. cit. stipra note 15, at 273.

${ }^{20}$ Sutherland, Critique of Sheldon's "Varieties of Delinquent Youth," I6 AM. Socrorogrcar. Rev. xo, 13 (1951). The original version of this paper is published in Cohen, Lindesmith, \& Schuesster, op. cit. supra note 15 , at 279,288 . (Emphasis added.)

21 BRIT. J DeLINQ. 297 (1953). 
a positive conception of the criminal is developed-namely, that of a category of persons who are constitutionally normal, functioning in a normal society.

\section{III}

In 1951, Vold wrote that, with the exception of Hooton and a few of his followers, no one today takes seriously the proposition that there are demonstrable physical differences between those who commit crime and those who do not. ${ }^{22}$ Vold's statement hardly applies to sociology, and even less to other disciplines. The defection of sociologists from the sociology depicted above can be exemplified with several illustrations.

Weinberg has suggested a shotgun marriage of constitutional psychology and sociology, but without specifying who would hold the gun and who would perform the ceremony. From the individualistic approach, the emphasis would be upon bodytype and temperament and several other components. From the group approach, the emphasis would be upon the type of neighborhood and the like. When combined, they would comprise a "unified approach." ${ }^{23}$ Weinberg, however, simply ignores a basic problem: How can the constitutional psychology of Hooton, Sheldon, and the Gluecks be "unified" with the social psychology of sociology, especially when the two present mutually-contradictory conceptions of man and theories of human behavior. Weinberg's study reminded Mrs. Datta of the parable of the gentleman who studied all of the available material on philosophy and all of the available material on China, and then wrote a book entitled "Chinese Philosophy" by adding together his two series of notes. ${ }^{24}$ To the extent that Weinberg adheres to constitutional psychology, he is logically estopped from claiming that sociology has any legitimate right to its own existence. Sheldon Glueck has very clearly recognized this important point, even if Weinberg has not. ${ }^{25}$

Caldwell is, in some respects, similar to Weinberg. On the one hand, he states that the efforts of Kretschmer, Sheldon, and others to show that bodily build is directly related to type of personality, and through this to crime, have failed. ${ }^{26}$ On the other hand, however, he at times openly asserts that biology and heredity enter into criminal behavior; and at other times, he seemingly is unaware that he is propounding biological theories. He is very close to an instinctivist view in his claim that "it is clear" that both competition and cooperation, as well as the other social processes, "have roots in heredity," but that "man's natural tendencies to strive" are greatly influenced by culture. ${ }^{27}$ He also writes $:^{28}$

... any theory of criminal behavior must include an examination of the biological and

20 Vold, Criminology at the Crossroads, 42 J. Carm. L., C. \& P.S. 157 (I95I).

${ }^{23}$ Weinberg, Theories of Criminality and Problems of Prediction, 45 J. CRIM. L., C. \& P.S. 421 (1954).

${ }_{24}$ DATTA, op. cit. supra note 5 , at 48 .

${ }^{25} \mathrm{~S}$. Glueck, Theory and Fact in Criminology, 7 Brit, J. Delive. 92 (1956).

${ }^{20}$ Robert G. Caldweli, Criminology 201 (1957).

${ }^{27} I d$. at 146 .

${ }^{28}$ Id. at 779 . 
psychological factors that influence man's receptivity to social influences and his adaptation to social situations.

Caldwell fails to indicate why a sociological theory must include biology and psychology. If he means that we could not act as we do were it not for our central nervous system, brain, stereoscopic vision, and so on, his statement is meaningless in the sense that none would disagree with it. But if he means that cultural experience is something added to our natural tendencies (whatever may these be?), he is antisociological in the sense that he is rejecting the social-psychological analysis of human behavior that has been developed during the past seventy years or so and which is known as symbolic interaction. ${ }^{20}$

Several passages indicate that Caldwell's position is meaningless as defined in the previous paragraph. In discussing his proposition that heredity may be "the major" factor in a criminal as well as a successful business or professional career, he writes that "heredity is a factor in criminal behavior-and an important one-just as it is a factor in all human behavior." ${ }^{30}$ Who would argue with this most general statement, and, also, just how does this "factor" of heredity become transformed into specific behavior in criminal, business, or professional activities? In discussing the "endocrinological factor," he offers us the facile statement that, ". . . although endocrinology has much to offer, it cannot provide us with a panacea for law violations."

It does seem as if Caldwell is commited to instinctivism, which is another theory of human behavior that sociology has shown to be empirically and logically incorrect. Thus, he writes of the person who is "naturally aggressive."32 $\mathrm{He}$ is also most unsociological in his criticism of the classical school of criminology. That school, he writes, "tended to direct attention from the criminal to the crime, and thus away from an inquiry into the causes of crime." ${ }^{33}$ The sociological position is, of course, that since crime is a sociocultural phenomenon, it is necessary to study it socioculturally in order to understand it.

That Caldwell's position is individualistic is shown in his praise of Lombroso. He writes that Lombroso "clearly" showed that we must "look beyond" crime and study the criminal if we want to learn the causes of criminal behavior. ${ }^{34}$ What

${ }^{20}$ Cooley, Genitu, Fame, and the Comparison of Races, 9 Annals 317 (1897), reprinted in Charles H. Cooley, Soctological Theory and Social Research c. 3 (1930).

${ }^{30}$ Caldwell, op. cit. supra note 26 , at 196 .

${ }^{31}$ Id. at 203. Hoskins, an outstanding research endocrinologist, is more modest about his ficld than Caldwell is: "Before psychology, sociology, and criminology can be convincingly rewritten as, mercly special aspects of endocrinology, many more facts than are now available will have to be collected and integrated. R. G. Hoskins, ENdocRinology 348 (r94I).

${ }^{39}$ Caldwell, op. cit. stupra note 26 , at 217 . For a moralistic commitment to instinctivism in relation to human sexuality, see Mabel A. Elliotr, Crime in Modern Soctety 229 (1952).

${ }^{33}$ Caldwell, op. cit. supra note 26; at 161 . (Emphasis added.) Shalloo presents the socialpsychological position in discussing the individualistic proposition that we must study a given boy in order to understand why he is delinquent. Shalloo says of this claim that "this is sound sense and acceptable science, if we may add that 'that boy' includes relationships, traditions, taboos, injunctions attitudes, restrictions, ambitions and a never-ending change and definition of all these in relation to 'that boy.'" Shalloo, Book Review, 42 J. Crim. L., C. \& P.S. 655 (1952).

${ }^{34}$ Caldwell, op. cit. supra note 26 , at 164 . 
Lombroso did was to study the "constitution" and the "heredity" of prisoners through physical measurements and post mortems, in a search for "stigmata" and "taints"-a combination of arithmetic and surgery that retarded the progress of criminology for more than fifty years. ${ }^{35}$ It has been observed by various students that the study of the individual criminal in the fashion popularized by Lombroso has resulted in a succession of conceptions of the criminal as being pathological, as follows: ${ }^{36}$

Psychiatric: neurologically pathological

Psychiatric: psychopathic

Psychological: mentally deficient

Psychological: abnormal personality

Psychonalytic: sexually repressed

Racialistic: inferior race or nationality.

None of these instinctivist, pathological concepts has endured the test of empirical and logical analysis, but Caldwell, nevertheless, associates himself with the perhaps least tenable.

It is necessary to call attention to Caldwell's methodological use of the concept "factor" in connection with the above discussion. ${ }^{37} \mathrm{He}$ employs it in a manner regrettably too common in the sociological literature on criminology; it would be tedious rather than difficult to cite this usage. ${ }^{38}$ The concept "factor" is not experimentally or logically derived from previous research, except that one writer will employ the "factors" enumerated by a previous writer, who did not derive them analytically. As will be seen in the discussion of the theory of multiple causation, there is no end to the factors that can be listed. In the above usage, a factor is a purely expedient and ad hoc concept, in the sense that it is anything that the investigator wants to study or to refer to at a given time.

It is frequently claimed that the sociological approach to criminology must be supplemented by anthropology, biology, geography, psychology, and psychiatry. Even though illustrations from these other fields may be supplied, there is no specification as to what theoretical supplementation will be provided by the other disciplines. No conceptual scheme is provided by which the different disciplines could be organically unified into a single discipline or into a single theory (not a single factor). Caldwell and Tappan provide two examples. Caldwell discusses "personal" factors in crime, under the following headings: : $^{39}$

${ }^{36}$ Lindesmith \& Levin, The Lombrosian Myth in Criminology, 42 AM. J. Socrotogy 653 (1937).

${ }^{30}$ Hartung, Methodological Assumption in a Social Psychological Theory of Criminality, 45 J. Crim. L., C. \& P.S. 652 (r955), summarizes these pathological conceptions.

${ }^{37}$ Caldwell, op. cit. supra note 26 , c. II.

${ }^{88}$ See Lowell J. Carr, Delinguency Control (2d ed. i950); Ruth Shonle Cavan, Criminology (2d ed. i955); Mabel A. Elliott \& Frances Merrill, Social Disorganization (3d ed. i952); Mabel A. Elliott, Crime in American Society (1952); Hans von Hentig, Crime: Its Causes and Conditioss (1947); Bernard Lander, Towards an Understanding of Juvenile Delinguency (I954); Reckless, op. cit. supra note 8; Martin H. Neuneyer, Juvenile Delinguency in Modern Society (2d ed. r955); Paul W. Tappan, Juvenile Delinquency (r949).

${ }^{30}$ Caldwell, op. cit. stipra note 26 , c. II. 
I. Heredity

2. Race

3. Physical Characteristics

a. Sex

b. Age

c. Anatomical and Physiological Factors

4. Personality Conflicts
5. Mental Abnormalities

a. Mental Deficiency

b. Mental Diseases

c. The Psychoses

d. The Psychoneuroses

e. Psychopathic Personality

f. Incidence of Mental Disease in

Criminals

One must ask the logical question: In what sense are these twelve "personal factors" actually personal rather than biological, genetic (hereditary), neurological, physiological, social-psychological, or statistical? In common with other such schemes, the personal, on second sight, seems to become something quite different. Mental deficiency, for example, may be organic. No neurological defect, however, has been found in the great majority of persons classified as mentally deficientl We will indicate briefly below that social-psychological concepts may also account for them. It is generally recognized that mental "disease" may be organic, or social psychological, or both. And what can possibly be personal in the statistical concept incidence?

Florita stated it to be his conclusion, based on intensive and prolonged study and experience in law enforcement, that: ${ }^{\mathbf{0}}$

Crime is essentially a social phenomenon and jurists and sociologists should study it, not doctors and biologists.

The modes of treatment of criminals should be sociological rather than medical, he argued further, and sociologists and educators should provide the therapy, not physicians or psychiatrists.

Paul W. Tappan, the attorney-sociologist, in discussing Florita's study, found it necessary to reject Florita's conclusions. Tappan wrote that he: ${ }^{41}$

... cannot agree to any proposition that biological and psychological factors are not causal [in crime].

Tappan had previously come to this position in his Juvenile Delinquency, in which he referred to the "significant psychological and constitutional factors in the individual that may enter into deviation." ${ }^{2}$ His fifth and sixth chapters are devoted to the listing and discussing of psychological and biological "causes and conditions" of delinquency. His list differs only in detail from Caldwell's and, therefore, need not be discussed beyond making two points briefly. First, if Tappan is correct, a science of behavior is impossible. He argues that both the observers and the

${ }^{40}$ Florita, Enquiry into the Causes of Crime, 44 J. CrIM. L., C. \& P.S. 5 (1953).

'Tappan, Florita's Enquiry into the Causes of Crime, id. at 20.

${ }^{20}$ Paul. W. Tappan, Juvenile Delinguency 79 (1949). Elliott is another who apparently belicues that the "innate constitution" plays a dynamic part in specific human actions. MAsBel A. Eltior, CkIME IN MODERN SOCIETY IO7 (1952). 
violators of law are "infinitely varied products"; the differences in personality and behavior of the law violators are "much greater than the uniformities of their antisocial behavior"; and even if they commit similar crimes, they are each "subjectively distinct" from one another because the similar behaviors have emerged from "particular configurations." 43

Second, his position is essentially psychological. To be sure, on the first page of the book, he claims that his third chapter presents a social-psychological theory of behavior, and he does refer to Charles Horton Cooley and George Herbert Mead. This claim is repudiated, however, by his emphasis that his is an eclectic approach and that "modern empirical research" is "increasingly eclectic." ${ }^{44}$ Tappan also seemingly conceives the individual in terms of an individualistic psychology: both the delinquent and the nondelinquent result from the influences of specific conditioning circumstances upon their reacting organisms. Further, the individual's power to inhibit the affective responses of the sympathetic nervous system is particularly important, "since here is [sic] manufactured the emotional responses of hate, anger, and fear."

The failure to maintain the distinction between an individualistic and a social psychology is by no means confined to Tappan. Cavan has an explicit and excellent statement in her Criminology, of a social-psychological explanation of human behavior. She employs the terms "social patterns," "behavioral roles," "self-conception," "community," and the like. ${ }^{46}$ She also states that no special theory is needed to explain criminal behavior, in the sense that it is unnecessary to posit criminal instincts, physical anomalies, or inborn mental quirks. This straightforwardly sociological approach, however, is compromised. Sociologists, she says, tend to overemphasize the social in experience; psychiatrists and psychologists, the individual and mental factors. "Obviously," she continues, "a correlation of the two approaches is needed."47

It is conceivably possible, in a given instance, to overemphasize one or another component in a situation. But Professor Cavan's is the same kind of facile statement that Caldwell makes. It conveys the impression of attempted fairness to the three disciplines, with no attempt to specify the legitimate limits of any one, so that a novice, a tyro, or even an expert could recognize the overemphasis. On page eleven, Professor Cavan refers to the sociological theory that criminal behavior develops from previous experiences. But by the bottom of page twelve, she is seemingly uncertain of her social psychology and claims only that "much, perhaps most" criminal behavior is learned.

${ }^{43}$ Paul W. Tappan, Juvenile Delinguency 65 (ig49). (Emphasis added.)

"Id. at 75.

${ }^{4} \mathrm{Id}$. at 65,67 . Tappan refers to electroencephalography as part of an "analytical and eclectic criminology." Id. at 76. Professor Michael Hakeem, of the University of Wisconsin, is preparing an appraisal of electroencephalographic studies that will soon be published. Some psychiatric studies have reported no significant difference between criminals and noncriminals, and no significant correlation between EEG and type of criminal behavior.

${ }^{10}$ Cavan, op. cit. stipra note 38 , at 13 .

${ }^{47}$ Id. at 12 . 
It may be that this uncertainty results from Professor Cavan adopting a psychology of needs and tensions. She begins with the assertion that all behavior is purposive. This is too inclusive for social psychology, which holds that only symbolic behavior, which utilizes some form of language, is purposive. ${ }^{48}$ The individual has "innate drives" and "urgent natural drives" (which are not described, listed, or otherwise specified), according to her psychology. When these innate drives are not organized and needs (unspecified) are not met in a realistic manner (undescribed), the resulting frustrations may be met, it is held, by an explosion, by introversion, or by indirection. "She is thus led, through the use of physical terms such as "tension" and "pressure," to the analogical I-beam theory of personality. Personality is likened to an I-beam, which can withstand much pressure if the moments of stress (tension) are equally distributed. If it is off-balance, through the fulcrum being off-center, the continued accretion of pressure will result in such tension that an additional increment of pressure, however infinitesimal, will cause a break.

Professor Cavan extends the physical analogy from the individual to the community in citing favorably a highly moralistic and condescending study on "community deviation pressures" by Carr. ${ }^{50}$ In the seventh chapter of his book, Carr discusses "deviation pressure," "deviation differential," "deviation expectancy," and "conformity pressures"; his table fourteen lists eleven "deviation pressure indexes." Some of the deviation pressures are: families without telephones or automobiles; houses without basements; individuals not attending church every Sunday; individuals aged twenty-one to sixty years not belonging to industrial, professional, and "etc." organizations; and individuals reading fiction instead of nonfiction! Neither Carr nor Cavan nor Caldwell give the slightest hint of the reasoning that resulted in the conclusion that these "indexes" constitute "deviation pressures" and are "delinquency-causing." What in the world can be delinquency-causing about reading fiction-even science-fiction? Or in not paying dues to some "etc." organization? Or about not attending church every Sunday, especially since this applies to the

" This point is explicated by the present writer in a chapter on "Behavior, Culture, and Symbolism," in a fortheoming volume, Anthropological Essays, to be published in 1959.

${ }^{10}$ Cavan, op. cit. supra note 38 , at 19. The individualistic psychology based on drives and needs, which is a modified form of instinctivism, has distinguished proponents in sociology. Thus, Thomas argued, some years ago, that the two real needs of human beings that explained so much of our behavior are sex and food. W. I. Thomas, The Configurations of Personality-The Unconscious: A Symposium (1927). Young also expounds a physiological psychology. Kimarle Younc, Basic Characteristics, Motivation and Emotion, in Social Psychology in (3d ed. 1956).

${ }^{50}$ Cavan, op. cit. supta note 38 , at I63; CARR, op. cit. supra note 38 , at 162 . Caldwell, op. cit. supra note 26, at 230, also accepts this study, with its analogy, naïve methodology, and moralism. Anyone who accepts "moral conformity (or) conformity to the mores of the neighborhood" as marking the normal home and some departure from this "moral conformity" as being a "deviation pressure" and "delinquency-causative" would live happily in Elmhurst. Illinois. In one subdivision of that community, every house (home?) must follow this formula at Christmastime: On the front lawn, erect a "Christmas tree" of specified height and species, a standard distance from the house, in the center of the lawn, bearing a standard number of electric bulbs of the same wattage, with the power to be turned on at the same time each evening, with arrangments for the latter to be done if one will not be in his house.

${ }^{51} \mathrm{CARR}$, op. cit. stpra note 38 , at 162 . The quotation marks indicate that the use of nouns to modify nouns is Carr's. 
overwhelming proportion of the population, the majority of whom do not even belong to any church? There would be implications for preventive programs if Carr or Cavan or Caldwell would specify the delinquency-causing qualities of houses without basements. One can anticipate: dig basements and reduce delinquency.

It should be explicitly stated, nevertheless, that Professor Cavan's Criminology is sociological, and that social psychology predominates over psychology. It is hardly possible to make the same statement concerning Reckless' work. Reckless also uses the physical terms "pressure" and "tension" in his exposition of the I-beam theory of personality, using picturesque, analogical, and confusing language. He writes of the offender whose violation is eruptive: ${ }^{52}$

Tensions have been welling up in him for a long time. He finally comes to a breaking point and "blows his top."

The fault, he says, may be in the person-“some lurking weakness or inadequacy." In four paragraphs, he uses physicalistic terms to describe personality and human behavior about thirty-eight times. ${ }^{53}$

The I-beam theory of personality-which is more common than the few citations here would indicate-in its concern with pressures building up, some weakness, whether or not lurking, and a breaking point, is on a lower theoretical level than the folk saying about the straw that broke the camel's back.

The explicit commitment to sociology and social psychology that is compromised often to mere lip-service through accepting some form of constitutional psychology, or through confusing individualistic with social psychology, or through the use of analogy, is common in criminology. Further discussion would be repetitious, but a few more references may be cited. ${ }^{54}$

The discussion thus far can be briefly summarized: The picture presented by the sociological approach to criminology is confused.

I. There is the claim that only a few people take constitutional psychology and its cognates seriously.

2. There are many who do take it seriously:

a. Some would unify constitutional psychology and its cognates with sociology.

b. Some explicitly reject it, but admit through the back door, biology, genetics, instinctivism, neurology, psychiatry, and individualistic psychology.

c. This is particularly evident in the writings of those students who place, under

${ }^{53}$ Rackless, op. cit. supra note 8 , at 73 .

${ }^{63}$ Id. at 79. Glueck does a little better on this than Reckless. In one paragraph, Glueck uses such physical terms as weight, pressure, scale (balance), energy, and force about eighteen times. Glueck, Theory and Fact in Criminology, 7 BRIT. J. DeLive. 92, 105 (1956).

ot Barnes, Criminology, 4 Encrc. Soc. Scr. 585 (I932); Harry E. Barnes \& Negley K. Teeters, New Horizons in Criminologr c. 6 (2d ed. I95I); Milton L. Barron, The Biology and Psychology of juvenile Delinquents, in The Juvenile in Delinquent Societr Io6 (1954); Beeley, $A$ Socio-Psychological Theory of Crime and Delinquency: A Contribution to Etiology, 45 J. CRIM. L., C. \& P.S. $39 \mathrm{I}$ (1954); John L. Gilmin, The Wisconsin Prisoner (1946); Hans von Hentig, The Crimmal and His Victim (1948); Neumeyer, op. cit. supra note 38; Donald R. TaFt, Criminology (3d ed. 1956); Negley K. Teeters \& John Otto Reinemann, The Challenge of Delinguency (1950); George B. Vold, in Theoretical Criminology i8 3 (I958). 
the category "personal," phenomena that logically are part of the disciplines listed under b. supra. Some even include statistics, which is certainly impersonal.

3. Confusion and misconception is perpetuated:

a. There is an expedient and ad hoc use of the concept "factor" in causal theories.

b. Some destroy the possibility of a behavioral science by claiming infinite variety between all human beings and greater differences than similarities between offenders.

c. There is an attempt to explain behavioral, psychical, and social phenomena by the use of physical terms and analogies.

4. There are some who are consistently and more or less systematically sociological and who try to be constructive through attempting to develop an integrative and unifying theory.

\section{IV}

Criminologists, among others, have been concerned with the problem of intelligence in relation to crime. Perhaps the reputation of sociologists for destroying rather than building is based largely on the fact that they have succeeded in practically evicting from criminology the serious consideration of low intelligence as the cause of crime, or even as a major or minor cause. Since various textbooks in the field present an adequate history of this, it is unnecessary to repeat it here. It should be stated, however, that in their attacks on the neurological and psychological hypothesis that the criminal is, on the whole, feeble-minded or of low intelligence, the sociologists were particularly constructive.

It seems that most, if not all, criminologists in this country accept the sociological conclusion that the criminal is a normal human being, at least as far as intelligence is concerned. Practically every textbook will have a statement comparable to that of Cavan or Clinard: statistical studies establish the fact that criminals are drawn from all levels of intelligence, in much the same proportion that these levels are found in the general population. ${ }^{55}$

Sociologists, in discussing intelligence in relation to crime, have generally proceeded from the social-psychological position of symbolic interaction, exemplified in the work of Charles Horton Cooley. ${ }^{56}$ In the first edition of his work, Cooley had shown that intellectual development is wholly a sociocultural process. He extended empirically the logical analysis of the philosophy of science developed by Peirce. ${ }^{57}$ In his second edition, Cooley showed that the results of intelligence tests could be explained more reasonably in terms of language, family life, education, and occupa-

\footnotetext{
${ }^{50}$ Cavan, op. cit. supra note 38, at 53; Marshali. B. Clinasd, The Soctology op Deviant Behavior irg (1957). George B. Vold, Theoretical Criminology (1958) has an excellent chapter on the history of mental testing and theories of feeble-mindedness in this field. It reveals very clearly the constructive character of the sociological approach to this problem.

${ }^{53}$ Charles H. Cooley, Human Nature and the Social Order (1902, 2d ed. 1922).

${ }^{57}$ Churles S. Peirce, Concerning Certain Faculties Claimed for Man, and Some Consequences of Four Incapacities, in 5 Collected Papers 135, 156 (1934).
} 
tion than by alleged hereditary differences between groups and individuals in the capacity to learn. The next year, Kroeber, in anthropology, was advancing the same argument. $^{58}$ Having thus empirically demonstrated that there is a social psychology of intelligence and having logically and empirically established their claim to investigate it, sociologists abandoned it to psychologists. It has languished with the latter until recently; some backsliding sociologists even assert openly that intelligence is no business of theirs.

Thus, the censure to be laid upon sociology is that it has refused to investigate a type of behavioral and sociocultural phenomenon whose existence it established against the strenuous resistance of psychology and several other disciplines-namely, the social psychology of intelligence. Three recent and excellent discussions of intelligence in relation to crime and delinquency are presented in Clinard, ${ }^{59}$ Sutherland and Cressey, ${ }^{60}$ and Vold. ${ }^{61}$ None, however, goes beyond the historical recitation and presentation of the conception of the delinquent and criminal as being just as normal in this respect as the population as a whole.

An admittedly incomplete search of the sociological literature of the past decade or so uncovered only one attempt on the part of a sociologist to assert the right of sociology to deal with the general problem of intelligence, independent of delinquency. The following discussion draws heavily on the study by Edward J. Ferentz. ${ }^{62}$

Many hospitals and state institutions make free use of the "familial" or "gardenvariety" type of mental deficiency. This is a class for which no neurological pathology of the brain or central nervous system has been found, but for which an hereditary mental defect is asserted or assumed. ${ }^{63}$ Sarason estimates that from fortyfive to fifty-five per cent of institutionalized defectives and from sixty-five to seventyfive per cent of noninstitutionalized defectives are of this garden-variety type. ${ }^{64} \mathrm{He}$ shows that the data necessary for meeting the criteria of mental deficiency are in practice usually not available. It "seems clear," he says, that the evaluation of the intelligence of parents and siblings is largely made on the basis of reports from secondary and tertiary sources. To confirm this last point, Sarason studied all twenty cases of children admitted to an institution during a six-month period who had been diagnosed as garden-variety defective. The twenty children were subjected to a precommitment test, usually the Stanford-Binet. Of the twenty mothers, only five had

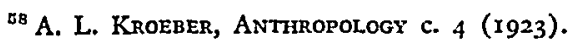

5b Marshall B. Clinard, The Sociology of Deviant Behavior il6 (1957).

in Edwin H. Sutherland \& Donald R. Cressey, Principles of Crimnology i17 (5th ed. 1955).

${ }^{62}$ George B. Vold, Theorettcal Criminology 75 (i958).

03 Ferentz, Mental Deficiency Related to Crime, 45 J. CrIM. L., C. \& P.S. 299 (1954). The following publications were consulted for the period since at least 1940: all of the textbooks in criminology, several of the books dealing with sociological theory, the American Joturnal of Sociology, American Sociological Review, British Journal of Sociology, Federal Probation, Journal of Criminal Law, Criminology and Police Science, and Social Forces.

os Yannet, Mental Deficiency, in A. G. Mitchell \& W. E. Nelson (Eds.), Textbook of Pediatrics 1274 ( 5 th ed. 1950).

ot Seymore B. Sarason, Psychological Problems in Mental Deficiency i02 (2d ed. 1953). 
been tested, and the data on one was not available; none of the twenty fathers had been tested; only twenty-five of seventy-six siblings had been tested, and they came from only eight of the twenty families. ${ }^{65}$

Tappan presents a case of a garden-variety mental defective who was delinquent to illustrate "hereditary influences" as one of the "biological causes" of delinquency. ${ }^{60}$ The girl had an I.Q. of 70 , neither she nor other members of the family were given neurological examinations, but she was still committed to an institution for the feeble-minded. The mere assertion of hereditary influence, illustrated in this case, is insufficient, particularly when it contradicts the social-psychological analysis of personality. That analysis views the development of personality in terms of the learning of sets of roles, the expectations associated with those roles, and the situations in which the roles are to be innervated. Such an analysis makes possible a conceptual continuity between personality and the garden-variety of mental deficiency. If one's organization of roles is learned through symbolic communication with others, then the garden-variety of mental defective can be shown to be socialized into his role as a mental defective! His socialization would not be due to any inherent mental defect, because without sufficient capacity, the entire complex process could not take place. ${ }^{67}$

Neither the theoretical nor the practical problems posed by the concept of mental deficiency or feeble-mindedness have been explored in any systematic fashion. Practically all psychologists and psychiatrists, as well as sociologists and social psychologists, have simply accepted the concept. ${ }^{68}$ In theory and in practice, the statement that a given person is mentally deficient has generally been stated as a neurological proposition. In most cases, however, the test of the proposition has been behavioral, not neurological. One of the things for which human behavior is notorious is that it is greatly influenced by experience. The most universal fault of biological theories of human behavior, including criminality, is that the theories are tested in terms of behavioral data, rather than biological data. It seems that this is the most devastating criticism that one can make, whether the theory is that of Glueck, Hooton, Sheldon, Tappan, or Caldwell. ${ }^{69}$

\footnotetext{
${ }^{05}$ Id. table 4 , at 102.
}

${ }^{00}$ Paul W. Tappan, Juvenile Delinquency 123 (1949). clusion.

${ }^{6 z}$ Sarason, op. cit. stipra note 64 , cc. $4-6$, presents a good deal of evidence in support of this con-

${ }^{8 B}$ The present writer is engaged in investigating some of the social-psychological problems related to the concept: the constancy of the intelligence quotient, the relationship between content of sociocultural experience and IQ, the methodology of test construction, and the relationship between selected aspects of parental background and child's IQ. See Sarason \& Gladwin, Psychological and Cultural Problems in Mental Subnormality: A Review of Research, 57 Genetic Psychology Monographs 3 (1957); Gerhart Saenger, The Adjustment of Severely Retarded Adults in the Conmunity (1957).

${ }^{30}$ The discussion has contended for the logical inclusion within sociology of the garden-varicty of mental "defective," thus extending the legitimate limits of sociology and criminology, as over against the implied claim of neurology and of (clinical) psychology for exclusive jurisdiction. For a discussion of psychiatric claims, see Hakeem, A Critique of the Psychiatric Approach to Crime and Correction, supra 650, as well as his two other excellent studies: A Critique of the Psychisatric Approach to the Prevention of Juvenile Delinquency, 5 Social Problems 194 (1958), and A Critique of the Psychiatric Approach, in Joseph Roucek (Ed.), Juvenile Delinquency 79 (1958). 
$\mathrm{V}$

It can be said, figuratively speaking, that sociology in general and criminology in particular has been, is, and will continue for some time to be schizophrenic on the problem and concept of social organization. One of the basic themes of the sociological analysis of human society is that of two fundamentally different types of social organization. These types, not mutually exclusive as societies exist in fact, are based on the principle of the homogeneity of groups within a society.

In the homogenous type, a common system of values possesses the members, so that they tend to act similarly in similar situations. This condition is referred to as "consensus." Many sociologists contend that consensus is synonymous with social organization. When consensus disappears, in the sense that competing systems of values exist in the same society, these sociologists hold that social disorganization has developed. We are said to have become a mass society.

In the heterogeneous type, a common system of values still maintains its hold upon the members. Free-standing groups have developed, however, that are, to some extent, emancipated from the common values in respect to conditions with which they are especially concerned. These groups develop a system of values specific to themselves and eccentric to the common system. This results in a societal condition in which all persons tend to act similarly in certain types of situations and differently in certain other similar types of situations. This is a condition referred to as "the rorganization of differences," 70 and more recently as "differential social organization."71 The following discussion will be concerned with the concept of social disorganization. Without attempting any historical summary, it can be said that the current usage of this concept results largely from its explication, but not necessarily elucidation, by Thomas and Znaniecki, who defined social disorganization as: ${ }^{72}$

... a decrease of the influence of existing social rules of behavior upon individual members of the group.

This conception and definition has been adopted in practically all of the textbooks dealing with social problems and all of the textbooks bearing "social disorganization" in their title that have been published since $1918 . .^{73}$ A number of sociologists have, unfortunately, adopted the concept as a major, if not the, explanation of crime. In so doing, they have also adopted all of the logical and empirical problems that accompany the concept. A few years ago, Mills, in a study of these textbooks, found in them a pronounced tendency for "society" to be conceived in terms of primary groups and small homogeneous communities. He also found their level of theoretical abstraction so low that they were hardly more than bodies of meagerly-connected facts, and marked by a paste-pot eclectic psychology to provide a rationale for their

${ }^{70}$ Charles H. Cooley, Social Organization 6i (igit),

71 Edwin H. Sutherland \& Donald R. Cressex, Principles of Criminology 157 (5th ed. 1955).

${ }^{72} 2$ W. I. Thomas \& Florian Znaniecki, The Polish Peasant in Europe and America iI28 (1918), reprinted in part in EdMund H. Volkhart (ED.), Social Behavior and Personaliti 233 (195I). See also W. I. Thomas, The Unadjusted Girl c. 3 (x923).

${ }^{23}$ A refreshing change is Marshall B. Clinard, The Soctology of Deviant Behavior (I957). 
facile analysis. ${ }^{74}$ Mills's study, objective as it is, and acidic in its very objectivity, is a damning indictment that could hardly be improved today, since so much of what he said still applies. In reading even the books published since I950, one receives the impression that the authors are small-town natives pointing with alarm to the big city as being the sink of iniquity. Thus, Elliott claims that "displaced" country people in this country, unaccustomed to the complexities and stimulations of city life, "are easy prey to the temptations of crime."75

Since Mills's analysis is still largely correct, it will be sufficient here merely to indicate two points concerning contemporary social disorganizationists. First, they are quite adept at self-contradiction. Second, the approach to whatever they write about in general and to crime in particular, is negativistic. Several examples will illustrate the first point.

Elliott says that unpunished criminals and recidivistic prisoners are the real criminals because: ${ }^{76}$

... they have organized their lives without reference to social values. They have justified their lifework ... on a basis of the material rewards. ...

Whatever hope there is for reforming the criminal, Professor Elliott continues, "must lie in some conversion of his values." The significance of the quotations is not that her moralism is showing, but rather that she has contradicted herself within two sentences. An amazing self-contradiction within a single sentence is her statement that "Organized crime is one of the amazing aspects of social disorganization ..."I77

Cavan also seems to contradict herself by referring to the simultaneous absence and presence of social controls: ${ }^{78}$

Community controls are weak, both because conventional institutions are weak or non-existent and because pernicious institutions flourish in floundering, leaderless communities.

\section{Lander states that: ${ }^{79}$}

[Certain areas of the city] are characterized by a general social instability and weakening of the social controls and norms which reflect themselves in a high delinquency rate for all groups....

.... One would expect a high delinquency rate in an area characterized by normlessness and social instability.

On the next page, however, Lander states that it would be "erroneous" to conceive of areas with high rates of delinquency as being "devoid of norms and group controls," since gangs are "highly regulatory" of the behavior of their members.

"Mills, The Professional Ideology of Social Pathologists, 49 AM. J. Socioloox 165 (1944).

${ }^{75}$ Mabel A. Elliotr, Crime in Modern Society 94 (1952).

is $1 d$ at 82 . (Emphasis added.)

${ }^{37}$ Id. at 135. Another self-contradiction can be found on p. 13; other instances of moralism can be found on pp. 134 and 136 .

${ }^{78}$ Cavan, op. cit. supra note 38 , at 94 .

70 Bernard Lander, Towards an Understanding of Juvenile Delinquency 65, 89 (1954). 
Caldwell writes that if social disorganization, defined as the decreasing influence of social control, persists, then $:^{80}$

... crime and delinquency tend to become institutionalized in certain ... neighborhoods ... subcultures favorable to law violation develop and the principal roots of professional and organized crime flourish.

A second characteristic of the social disorganizationists is that their analysis of society and of crime in particular is negativistic. Crime is conceived-and so are the various other social problems-as resulting from the breakdown, the disintegration, or the failure (all three terms are used) of society as a whole, or of specific institutions. Society is "sick" or "delinquent," and the individual, particularly the juvenile, is its victim. This is an old man's conception-namely, the notion that today's morals have degenerated, while yesterday's were advanced and refined. It is the biblical mythology of the Fall, popularized in sociology by the "Chicago school." The reductio ad absurdum of this position is the rather frequent assertion that individuals abandon social dictates and follow the lead of individual impulses into irregular or criminal behavior.

With the exception of writers of textbooks, the trend of current publication and research is away from social disorganization. Recently, good textbooks have been written that do not depend on the concept. ${ }^{81}$ One can cite two reasons for this trend: First, common sense was too much for the absurdities of social disorganization. Students often ask, "If we are actually so disorganized, how were we able to win two world wars and recover from the worst depression in our history, and why doesn't this country collapse over night?"82 Second, much, if not most, of the recent criminological (etiological) research and also of correctional research has found social disorganization and its related concepts unworkable, unnecessary, and incorrect. This research does not find that individuals are progressively freed from social restraint, being thus (relatively) free to act on the basis of chance, or at random or fancy. It does find that in a heterogeneous society, the constraining influence of one value-system is substituted for another and that individuals characteristically are possessed by more than one value-system. One of its important conclusions is that social control is not diminished in a heterogeneous society. This research is, in part, based on the conception of social organization as consisting of the organization of differences. ${ }^{83}$ Some of its concepts are: role, reference group, subculture, self, motivation, differential association, differential identification, and differential social organization.

\footnotetext{
${ }^{\text {so }}$ Caldwell, op. cit. supra note 26 , at $\mathrm{r} 78$. Other self-contradictions will be found on pp. 143 and 223, and betwcen pp. 144 and 15I. Caldwell is the worst offender in this respect, because he scolds Sutherland for using the term "social disorganization," although he himself uses it more than roo times, often as an explanatory device and without strict definition. $C f$. id. at 183 .

${ }^{81}$ E.g., Marshall B. Clinard, The Sociology of Deviant Behavior (1957).

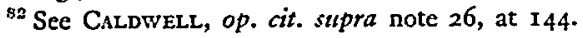

${ }^{83}$ Esemplified in Charles H. Cooley, Social Organization pt. 2 (I917).
} 
VI

Current sociological research on crime and delinquency rejects the motto, facilis descensus Averno, as being sociologically incorrect. In contrast, it holds that crime and delinquency are most usefully and correctly conceived as positive phenomena of the sociocultural process. Delinquency is conceived as a definite achievement, often the result of years of prolonged effort and hard work. It also holds that the same sociocultural processes that produce the criminal person produce the lawful person. This indicates why the sociological and social-psychological view is superior to others: it brings the widest range of behavioral, cultural, and social phenomena within the scope of a single theory. It is, therefore, unnecessary to invent specific pathologies to explain specific problems.

Much of the current research is concerned with developing a systematic and unifying theory and with establishing, therefore, the logical limits of criminologywhich would also, of course, help to establish the logical limits of sociology, since the two have grown together, at least in this country. Two examples will suffice: white-collar crime and sexual offenses.

Sutherland published his book, White Collar Crime, in 1949, incorporating several previously published papers. The book, he said, was a study in the theory of criminal behavior: "It is an attempt to reform the theory of criminal behavior, not to reform anything else." ${ }^{84}$ The negative theoretical thesis of the book is that biological, personal, and social pathologies are an inadequate explanation of criminality, because they are wholly unable to explain the data of white-collar crime. Its positive thesis is that the theory of differential association perhaps fits the data of criminality, including white-collar crime, better than any other general hypothesis. ${ }^{85}$ Other investigators published empirical research on white-collar crime, the amount of which is too great to cite completely ${ }^{86}$ Many criminologists accepted the concept of whitecollar crime, recognizing its great theoretical significance. First, it freed criminology from its empirical dependence on Uniform Crime Reports. Second, it offered another means to test the various pathological theories of crime. Third, it extended the logical limits of criminology by laying claim to that vast body of crime that is no concern of municipal, county, and state police departments and which is, therefore, "unknown" as far as those departments and the Federal Bureau of Investigation are concerned.

Some criminologists, however, rejected the concept "white-collar crime" in whole or in part. Their objections, in general, were either to the concept itself, or to the

\footnotetext{
se Ejwin H. Sutherland, White Collar Crime v (1949).

${ }^{85} I d$. at 6,234 .

${ }^{86}$ Marshall B. Clinard, The Black Market (1952); Frank E. Hartung, Law and Social Dipherentiation (1949); White-Collar Offenses in the Wholesale Meat Indzustry in Detroit, 56 AM. J. Socrovooy 25 (1950), White Collar Crime: Its Significance for Theory and Practice, Fed. Prob., June 1953, p. 31; and Common and Discrete Values, 38 J. Soc. Psychology 3 (1953); Lane, Why Business Men Violate the Law, 44 J. CRIM. L., C. \& P.S. 15I (1953); Newman, Public Attitudes Toward a Form of White Collar Crime, 4 Soctal Problems 228 (1957).
} 
inclusive theory of differential association, or both. The objections to the concept itself will be considered first.

Burgess objected that the concept, as defined in research, was too legalistic; Tappan, that it was too sociological. ${ }^{\$ 7}$ Caldwell, a strident critic of the concept who does not understand it very well, had several objections. First, there are minor variations in its definition from one researcher to another. Caldwell suggests that until unanimity can be achieved, the concept should be discarded altogether. One might just as well suggest that until the critics can agree as to what is wrong with the concept, they should remain silent. It would be employing Caldwell's logic to suggest that legislatures cease enacting laws until the forty-eight states are unanimous in their definitions of crimes. Second, Caldwell alleges that Sutherland, Clinard, and Hartung disregarded the important element of conviction. This is not true, as will be shown below. Third, he wants to protect the right of the businessman not to be called a criminal unless and until he has been convicted in a criminal court, ${ }^{88}$ which is what Tappan wants, and also Vold, who objects to the "paradox" in the proposition that "a community"s leaders and more responsible elements are also its criminals." 89 If Vold had written that some leaders and more responsible citizens are also among its criminals he would have reported accurately the sense of the literature. No proponent of the concept has claimed, at least in print, that a community's leaders are its criminals.

The above three hearts who bleed so profusely for the maligned businessman and for Anglo-American jurisprudence leave one untouched. First, they in effect argue that no crime has been committed and that no person is a criminal until there is a conviction for that crime. This is an absurdity. They confuse the commission of a crime with the conviction for its perpetration when they discuss whitecollar crime. But when they discuss the limitations of criminal statistics, they all agree-as does everyone else-that many persons who commit crimes are not even apprehended, let alone convicted. Second, they all accept Uniform Crime Reports, even though it deals largely with arrests. Much, of course, stands between arrest and conviction. They are, thus, not as solicitous of the lower class being branded "criminal" as they are of the upper class. Third, of all the critics of white-collar crime, only Tappan enters court with one clean hand.

Among the critics, only Tappan has protested against the broadening of the concept of delinquency to include the nondelinquent. He writes that the trend ${ }^{80}$

... to expose so-called predelinquents to the unofficial treatment of courts, police bureaus, and other authoritarian and nonspecialized agencies is a dangerous consequence of loose definitions and of indiscriminate prophecy from inadequate data.

Tappan's stricture, of course, applies to such inventions as the Gluecks' "causal law"

${ }^{97}$ See Burgess, Comment, 56 AM. J. Sociology 32 (1950); Tappan, Who Is the Criminal?, I2 Am. SOCIOLOGICAL REv. 96 (1947).

${ }^{B B}$ Caldwell, op. cit. supra note 26 , at 67.

${ }^{80}$ George B. Vold, Theoreticaz, Criminologx 253 (I958).

${ }^{\circ 0}$ Tappan, Sociological Motivations of Delinquency, ro8 AM. J. PrChintry 680 (1952). 
and "prediction tables" and Kvaraceus' "delinquency proneness scale."11 Lewis Diana, in a brilliant analysis, has shown that in many jurisdictions, there has been a removal of virtually all the procedural safeguards of the penal code in the juvenile court and the formulation of a conception of that court which makes it a childguidance agency supported by the compelling power of the state. ${ }^{02}$ Neither Caldwell nor Vold have made a comparable protest.

It seems that none of the critics has undertaken empirical research in the area of white-collar crime. That research reveals several matters of theoretical importance. First, well-established businessmen have been convicted. One study shows the following convictions among a total of 122 cases: three prison terms only, twenty-two fines only, twelve combined prison term and fine, six suspended prison terms, and eight probation only. ${ }^{93}$ The New York Times of April ro, $195^{8}$ reports that the owner of a tenement in Niagara Falls was sentenced to two to five years in prison. Fifteen children and three adults had burned to death; regulations concerning fireproofing, partitions, and exits had not been observed. Second, there are, as yet, no criteria by which seriousness of an offense can be judged, if the proceeding is civil rather than criminal. Many laws regulating business provide for both types of proceedings, but the criminal proceeding is permissive, not mandatory. A reading of the cases in the files of the Detroit office of the Office of Price Administration revealed that, in a number of civil proceedings, the violations were "wilful and calculated," which is to say they were criminal. Nonjuridical considerations led to the choice of the civil rather than the criminal remedy. When the federal antitrust law was enacted, providing for both civil and criminal process for the same violation and making the criminal proceeding merely permissive, was not "copping a plea" legalized for the businessman? Newman has undertaken some excellent research on "pleading guilty for considerations." ${ }^{4}$ Third, there are striking parallels, as Sutherland showed in White Collar Crime, and as confirmed by Clinard and Hartung, between "ordinary" crime and white-collar crime.

It seems that the concept is here to stay and that empirical research related to it is logically forcing a reappraisal of all extant theories of crime. And the concept has, very importantly, extended the logical limits of criminology by bringing within its purview all who have violated criminal laws, not only the adults apprehended by the police, and juveniles.

Some objection was voiced to white-collar crime because Sutherland explicitly related it to his theory of differential association. That theory, formulated in I939 in the third edition of his Principles of Criminology, has been under continuous discussion since its publication. It is the most sociological of all the theories that have

\footnotetext{
91 William C. Kvaraceus, The Community and the Delinguent c. 5 (r954).

${ }^{82}$ Diana, The Rights of Juvenile Delinquents: An Appraisal of Juvenile Court Procedures, $47 \mathrm{~J}$. CRIM. L., C. \& P.S. 56r (1957).

${ }^{93}$ Frank E. Hartung, Law and Social Differentiation 252 (1949).

"Newman, Pleading Guilty for Considerations: $A$ Study of Bargain Justice, 46 J. Crum. L., C. \& P.S. 780 (1956); Donald J. Newhan, A Study of Informal Processes in Felony Convictions (unpublished thesis in University of Wisconsin Library 1954).
} 
been developed in the attempt to account for crime and delinquency. It is, indeed, more-by extrapolation, it is a sociological attempt to account for human social behavior in terms of social organization and culture, employing a social-psychological orientation. The theory has been neglected by some, rejected by some, and accepted by some. Psychiatrists have, in general, neglected it. Criticisms have ranged from the vitriolic ${ }^{95}$ to the incomprehensible, ${ }^{96}$ and from the carping to the unfair. Perhaps the best example of unfair criticism is by Caldwell, who insisted on discussing and dissecting Sutherland's I939 version, even while he had the I947 and I955 versions in front of him. ${ }^{97}$ Caldwell takes Sutherland to task for modifying his theory through the years! Sutherland modified it because its scope was to be expanded on both empirical and theoretical grounds. Caldwell also seems to be irritated because Sutherland and Cressey account for "negative cases" (good or nondelinquent boys) in terms of social organization, without resorting to the mysticism of "personal factors," "free will," and the like, as Caldwell does. ${ }^{98}$

Most of the theoretical controversy and development, as well as empirical research, of the past several decades can be discussed in relation to the theory of differential association. Some of the items are: the character of a sound criminological theory, delinquent subculture, the relation of social class to delinquency, social structure and roles, nondelinquent and delinquent boys, concealed (unreported or undetected) delinquency, self and identification.

Perhaps the first result of the formulation of the theory was to call into question the theories of multiple causation. Explicitly started by Healy, accepted by Burt, and slavishly followed by the social disorganizationists, multiple causation has remained a popular and facile conception. ${ }^{99}$ Sutherland himself started with this popular notion, saying, ". . . I had a congeries of discrete and coordinate factors, unrelated to each other, which may be called the multiple-factor theory." ${ }^{100}$ Datta says that one cannot take the best of many disciplines, mix them, and emerge with "theory, eclectic." The eclectic view is not theory, she says, but hodge-podge. ${ }^{101}$

Cohen, in one of the best critiques of the multiple-causation approach, makes three points. ${ }^{102}$ First, there has been a failure to distinguish explanation by a single factor from explanation by a single theory. A theory deals with a number of

${ }^{\circ 5}$ Glueck, Theory and Fact in Criminology, 7 Brit. J. DeLine. 92 (I956), says that the theory is, "at best," general and puerile.

${ }^{08}$ Gill, An Operational View of Criminology, I Arch. Crm. Psychodyn. 3 (r957).

${ }^{97}$ Caldwell, op. cit. supra note 26 , at $18 \mathrm{I}$.

${ }^{08}$ Id. at 225. Caldwell has a fairly good restatement of differential association, but does not refer to it by name. Id. at $25 \mathrm{I}$.

${ }^{00}$ Wilimam Healy, The Individual Delineuent (Igr3); Crril Burt, The Young Delinquent $574-83$ (1925).

${ }^{100}$ Cohen, Lindesnath, \& Schuessler, op. cit. supra note 15 at 14 . This account by Sutherland of the development of his theory is a record of intellectual honesty and modesty, rarely encountered in one who has achieved pre-eminence in his field. This book very likely will give impetus to further empirical and theoretical research.

${ }^{101}$ DatTh, op. cit. supra note 5, at 15.

${ }^{202}$ Albert K. Cohen, Juvenile Delinquency and the Social. Structure (unpublished thesis in the Harvard University Library 1951). 
variables, which it organizes and relates to each other. But neither a statement of one factor nor of a number of factors about crime is a theoretical explanation of crime. Second, "factors" tend to become "causes," and each factor is assumed to contain within itself a fixed amount of delinquency-producing power. ${ }^{103}$ Third, the fallacy that "evil causes evil" is employed. The fallacy is that "evil" results (delinquency) must always have "evil" precedents (broken home, psychopathy, and the like). Recent research has no need for multiple causation, but, like astrology, it is likely to be with us for some time.

The work of Shaw and McKay in establishing the existence of a delinquent and criminal subculture is so well known in the field that it need not be repeated here. Much of the research has confirmed their findings, but has refined the techniques employed in the research and modified and expanded the theoretical discussion, leading toward a generalizing and integrative theory. A good deal of the research on crime and delinquency in England during the past decade or so falls in this category. Morris, for example, in his study of delinquency in Croydon, shows that in the theory of differential association, mobility and interstitial or deteriorated areas are not crucial or directly causal. ${ }^{104}$ What is crucial is the content of the tradition of the area, the first-hand relationship of younger boys with older delinquent boys, of the latter with young adult criminals, and of the latter with older adult criminals; and impersonally, the persisting subcultural system of crime and delinquency. Morris, however, very often employs the term "ecological" where usage in this country would dictate "social-psychological" or "sociocultural." One of the great values of Morris" book is his lengthy historical chapter on research during the nineteenth century, which helps to establish the legitimate claim of sociology to the field of criminology.

Lind found that in Honolulu, the spatial distribution of delinquents' homes, cases of dependency, arrests in connection with commercialized vice, and suicides, tended to follow the same spatial pattern as in cities in this country. ${ }^{105}$ Lind also found, as an aspect of social organization, that while the conservative influence of the immigrant community tended to shield the individual from cultural conflict, it often tended to bring him into conflict with the law.

Shannon undertook an ingenious and painstaking study of the distribution of criminal offenses by states, for the years 1946 through $1952 .^{100}$ His research supports the hypothesis that crime is largely a function of social and cultural influences. Since great differences in criminal rates on a regional basis persist over a period of time, one may hypothesize that subcultural variations of a regional character are responsible

\footnotetext{
${ }^{103}$ For an example of the ease with which "factors" become "causes," sec Elliott, Perspectite on the American Crime Problem, 5 Sochal Problems 184 (x958).

${ }^{104}$ Terence Morris, The Criminal Area (1958).

${ }^{105}$ Lind, Some Ecological Patterns of Community Disorganization in Honolulu, 36 AM. J. Socioloor $206($ (y930). (1954).

Shannon, The Spatial Distribution of Criminal Offenses by States, 45 J. CR1M. L., C. \& P.S. 264
} 
for these regional patterns of crime. The demonstration of the constancy of social phenomena is basic to the sociological view.

Clinard's research on rural offenders tends to support the theory of the functioning of a criminal culture. ${ }^{107}$ Conceiving urbanization. as a way of life marked by size, density of population, heterogeneity, and impersonality in interpersonal relations, he studied offenders from villages, small towns, and cities in Iowa. Differential association tended to vary directly with the degree of urbanization in the locality from which the boys came. Rural "gangs," when they were found, were only loosely organized. Clinard concluded that the closely-organized gangs of the city can exist only to the degree to which social relations tend to be impersonal. This is, however, still open to question, because rural crime has not been extensively studied with reference to its frequency and degree of organization. Esselstyn's study of the county sheriff is a case in point. ${ }^{108}$ He found that the ideal sheriff, as a social type, was a mature man with a good reputation and a knowledge of farming. Experience in law enforcement was unnecessary; interpretations of the law were very broad, being controlled by local custom. The sheriff had a high tolerance for certian types of lawlessness: the conduct of agriculture was outside the law. This confirms Sutherland's view on white-collar crime-namely, that some of the favored groups' business practices, while illegal, do not result in legal action. England is of the opinion that in towns in which the police force ranges in size from one to about seven men, the "city-fathers" largely determine what laws and ordinances will be enforced, and against whom. ${ }^{109}$

There are many other significant empirical studies which confirm the sociological conclusion that crime and delinquency are positive achievements of individuals participating in a social organization marked by a criminal subculture and tradition that is crucial in the maintenance of crime and delinquency. The following references are by no means a complete inventory. ${ }^{110}$ Among the most important of the

${ }^{107}$ Clinard, The Process of Urbanization and Criminal Behavior, 48 AM. J. Socrozogy 202 (r942). ${ }^{109}$ Esselstyn, The Social Role of a County Sheriff, 44 J. Crim. L., C. \& P.S. 177 (1953).

${ }^{100}$ Ralph W. England, Jr., in a personal communication. Eastman undertook a replication of Clinard's study, which at least in part confirmed Clinard's results. Harold D. Eastman, The Process of Urbanization and Criminal Behavior: A Restudy (unpublished thesis in University of Iowa Library I954). Clinard's replication of his own study in Sweden, in 1954-55, will soon be published. Clinard's position was also partially confirmed by Lentz, Rural-Urban Differentials and Juvenile Delinquency, 47 J. Crim. L., C. \& P.S. 33 I (1956).

Some other aspects of rural crime that could be studied are: the Ku Klux Klan, "mortgage holidays" to prevent the auctioning of farms, violations of game laws, illegal slaughtering of calves and cattle, violations of laws and regulations controlling acreage, the cheating of sharecroppers, and failure to pay state sales taxes on farm produce sold.

${ }^{210}$ Baker, Juvenile Delinquency and Housing in a Small City, 44 J. CRIM. L., C. \& P.S. 442 (1954); Parental Organizational Affiliation and Juwenile Delinquency, id. at 204; Deutscher, The Petty Offender: A Sociological Alien, id. at 595; Lane, supra note 86; Kobrin, The Conflict of Values in Delinquency Areas, I6 AM. Sociological Rev. 653 (195I); Clinard, Criminal Behavior Is Human Behavior, Fed. Prob., March I949, p. 2I; Pauz L. Crawford, Daniel I. Malamud, \& James R. Dunmpson, Working with Teen-Age Gavgs: A Report on the Central Hardem Streets Project (1950); Hakeem, Service in the Armed Forces and Criminality, 37 J. Crim. L. \& CRIminglogy 120 (1947); M. A. Straus \& J. H. Straus, Suicide, Homicide, and Social Structure in Ceylon, 58 Am. J. Sociology 461 (1953): 
recent researches is the work of Cohen on delinquent boys. ${ }^{111}$ The subtitle of the book refers to its major task: to account for the delinquent culture of the gang in sociological and social-psychological terms. The problem is discussed in relation to class structure, cultural change, and role-playing. Cohen conceives the development of a delinquent subculture as a process that builds, maintains, and reinforces a code of behavior that stands, in some respects, in a point-to-point inversion of the dominant (middle-class) values. The delinquent subculture is held to be developed and maintained as a solution to the problems confronted by the lower-class youth that relate to status. Middle-class male delinquency, Cohen tentatively hypothesizes, is quite different. It is a consequence of the middle-class adolescent boy's anxiety concerning his masculine role. Cohen's book shows that good criminology is good sociology: the same social processes and the same set of concepts and logical assumptions account for both delinquency and lawfulness.

Two appraisals of Cohen's work have appeared, which have significance for the general sociological proposition of the existence of a criminal culture and its crucial role in the crime and delinquency of the individual. Wilensky and Lebeaux have some very thoughtful comments to make on Cohen's work. ${ }^{112}$ They accept his general position and recognize, for example, that there may be a number of somewhat distinct subcultures. Their principal criticism is of Cohen's interpretation of middle-class male delinquency as being a response to the boy's problem of masculine identification. They hold that the problem of identification with his sexual role presents a relatively more pressing problem to the lower-class boy. $\mathrm{He}$ is subject to ridicule much earlier and in a different manner than the middle-class boy if he cannot sexually "prove" himself a man. Thus, the lower-class boy has two sources of anxiety: one relating to occupational and financial security, the other relating to his sexual role as a man. They predict, on this basis, that the working-class boys will be more delinquent than the official statistics show.

There are two replies to this criticism. First, it is generally recognized that there is a gap of unknown size between "actual" and "known" delinquency. Some students think that few if any adolescent boys in high-rate areas escape delinquency. Second, there is reason to doubt that delinquency is as concentrated among lowerclass males as Cohen had argued in his book; and Cohen himself now doubts that

Wood, Minority-Group Criminality and Cultural Integration, 37 J. Crm. L. \& Cruminozocy 498 (1947). Among the books presenting significant research and/or theoretical development are: J. H. BAGOT, juvenile Delinquency: A Comparative Study of the Postion in liverpool and England and Wales (x941); A. M. Carr-Saunders, Herman Mannhem, \& E. C. Rhodes, Young Oppenders (r942); M. P. Carter \& P. Jephcott, The Soctal Background of Delinquency (typescript in the University of Nottingham Library 1954); Lewis Coser, The Social Functions of Conflict (1956); Donatd R. Cressey, Other People's Money (1953); Alfred R. Lindesmitt, Opiate Addiction (i947); Herman Mannheim, Juvenile Delinguency in an English Mrddletown (I948); John B. Mays, Growing Up in the City (1954); Georg Simmer, Conflict and the Web of Group-Affiliations (Kurt H. Wolff transl. T955); Bettry M. Spinley, The Deprived and the Privileged (1953); Leslie A. White, The Science of Culture (1949); W. F. Whyte, Street Corner Societr (2d ed. 1955). 121 Albert K. Cohen, Delinquent Boys: The Culture of the Gang (1955).

${ }^{112}$ Harold A. Wilensky \& Charles N. Lebeadx, Industrial Societri and Soctal Wetopare (1957). 
delinquency is as class-related as he had once thought. The best evidence that Cohen can find for modifying his position is the research on "reported" delinquency by Short, which will be discussed brielly below.

The second critical question raised concerning the criminal subculture seems, at first reading, to question its very existence. ${ }^{113}$ Sykes and Matza show that the delinquent subculture is not completely opposed to the dominant culture. Delinquent boys have values in common with other boys: they experience guilt and shame, respect the "really honest" person and detest the hypocrite, distinguish between those who can be victimized and those who cannot, and accept many of the demands for conformity made by the dominant system of values. Sykes and Matza make a definite contribution to the analysis of human behavior in their concept, "techniques of neutralization" (rationalization), by which they mean the process of reasoning through which the boy goes before his delinquency. It emphasizes that delinquency, being purposive in one way or another, results, in part, from the way in which the individual conceives himself in relation to others.

Grosser's work on the sociology of sexual differences in juvenile delinquency is the only notable contribution in this area. ${ }^{114}$ Grosser applied role theory to this problem and analyzed the instrumental and expressive significance of the varieties of delinquent behavior in the content of different sexual roles. If one may damn with faint praise, Grosser's work is infinitely superior to Pollak's on the criminality of women. Pollak found that in their crimes, women were deceitful, deserted their husbands and families, and concealed their crimes. ${ }^{115}$

A small but important study by Mitchell has many implications for theories of delinquency. ${ }^{116}$ Mitchell ascertained the informal bases on which officers of the Youth Bureau of the Detroit Police Department decided, during their initial contact with a boy in the street, to handle his case formally or informally. There was a lack of uniformity among the officers studied in relation to the manner in which they handled cases of automobile theft, unarmed robbery, sexual offenses, larceny, and breaking and entering. If the family seemed to the officer to be interested in the boy and if the home was neat, the case tended to be handled informally. Children of "above average" intelligence had a good chance of being referred to an agency. If the boy was respectful to the officer and cooperated, he had a good chance of being released. Most officers would release a child to a church any time an affliation was acknowledged. A boy large for his age was handled formally: "I refer most big boys to court," said one officer. The last criterion for making a decision

${ }^{113}$ Sykes \& Matza, Techniques of Neutralization: A Theory of Delinquency, 22 Am. Soctological. REv. $66_{4}$ (1957).

114 George H. Grosser, Juvenile Delinguency and Contemporary American Sex Roles (unpublished thesis in Harvard University Library 1952); A Study in the Sex Specificity of Juvenile Delinquency, a paper read at the meeting of the American Sociological Society, 1955 (to be published).

${ }^{215}$ Ottro Poltak, The Crmminalty of Women (I950). Elliott had no trouble in replying to Pollak. Mabel A. Elliott, Crime in Modern Society 199 (1952).

${ }^{110}$ George A. Mttchell, The Youth Bureau: A Socrological Study (unpublished thesis in Wayne State University Library 1957). 
would certainly affect any study of "constitutional psychology" made of delinquents in Detroit.

The theory of white-collar crime, which indicates a class differential in criminality, has helped to re-open the entire problem of the relationship between social class and crime. Most of the studies of the delinquent subculture find that delinquency is a lower-class phenomenon. A highly-sophisticated attack on this problem has developed recently, to a certain extent through dissatisfaction with official statistics. This is a method for obtaining data by sampling directly from children in the community, referred to by Cohen, ${ }^{117}$ and employed by Short. The controlling criterion in this is the representativeness of the sample. This means that the children supply the information as to who is delinquent and nondelinquent and what the social and personal correlates of delinquency are. There are many difficulties to be overcome, and the research already published indicates some of them, as it also indicates some of the ways in which they can be overcome. It is a kind of research that has great potential implications for the study of delinquency and a general theory of criminality. ${ }^{118}$

The theory of differential association is presently being tested in reverse. This is an attempt to account for the "good boy" in areas with high rates of delinquency. Some years ago, Dunham reversed the usual question about mental abnormality and crime and addressed himself to the question of how many schizophrenics are criminals. The result was the most revealing study of the relation of insanity (psychosis) to crime published until that time. Practically none of the young schizophrenic males was criminal. In their personal characteristics, they revealed those traits that are revered in adolescent males by the Boy Scouts and the Y. M. C. A. ${ }^{119}$

Dinitz and Reckless have addressed themselves to the question of what is the process through which nondelinquent boys in areas high in delinquency, remain nondelinquent. ${ }^{120}$ They found that the major differences between the potentially delinquent and nondelinquent boys to be in self-conception, in type and content of interpersonal relationships, in contact with or conceptions of officials, school, home, and parents, and in choice of companions. Dinitz and Reckless suggest that a "socially appropriate" or inappropriate conception of self and other is the main factor

${ }^{117}$ Albert K. Cohen, Delinquent Boys: The Culture of the Gang 169 (1955).

${ }^{118}$ Nye \& Short, Scaling Delinqtent Behavior, 22 AM. Sociolagical Rev. 326 (1956); Nye, Short, \& Olson, Socio-Economic Status and Delinguent Behavior, 63 AM. J. Sociolocy 381 (1958); Short \& Nye, The Extent of Unrecorded Juvenile Delinquency (to be published in a forthcoming issue of the Journal of Criminal Law, Criminology, and Police Science); Reported Behavior as a Criterion of De. linquent Behavior, 5 Social Problems 207 (1958).

${ }^{110}$ Dunham, The Schizophrene and Criminal Behavior, 4 AM. Sociological. REv. 352 (1939).

${ }^{120}$ Reckless, Dinitz, \& Murray, Self Concept as an Insulator Against Delinquency, 21 Am. Sociolocical Rev. 744 (1956); The "Good" Boy in a High Delinquency Area, 48 J. Cr1M. L., C. \& P.S. 18 (1957); Dinitz, Reckless, \& Kay, Delinquency Proneness and School Achieventent, 36 ED. Res. BuL.. 13I (I957); The Self Component in Potential Delinquency and Potential Non-Delinguency, 22 AM. Sociological Rrv. 566 (1957). See also Short, Differential Association with Delinquent Friends and Delinquent Behatior, $\mathrm{x}$ PaC. Sociozocical Rev. 20 (I958). 
influencing a youth away from or toward delinquency. This hypothesis should explain not only delinquency, but also the "good" boys in high-delinquency areas and the delinquent youth in the low-delinquency area. It will be recognized that in this research, Dinitz and Reckless commit themselves to the symbolic interactionist school of social psychology. They are, incidentally, dealing with the concept cause in this research, which is far removed from the "risks" that Reckless was so fond of in The Crime Problem.

There has been a convergence of research and theory in criminology and social psychology, as indicated by the work of Dinitz and Reckless. Another contribution has been made by Glaser, which generalizes the kind of work performed by the former two on "good" boys. Glaser employs the concepts of self, other, role, identification, and reference group to meet objections raised to the theory of differential association..$^{121}$ The conception of behavior as role-playing presents individuals as directing their actions on the basis of their conceptions of how others conceive them. The choice of another person or group, from whose perspective one's own behavior is viewed, is the process of identification. It is the identification of self and with the other. The other may be real or imaginary, physically present or absent, a person or a group. We may be loyal, said Cooley, to a higher morality than that of the present. The process of rationalization-the defining of self and other in the context of the given situation-is necessary to voluntary behavior, particularly when one must choose between competing roles. Role-imagery, Glaser shows, provides the most comprehensive and interconnected theoretical framework for explaining the phenomena of criminality. ${ }^{122}$

The identification of self with one or another person or group and the selection of a role is referred to by Glaser as "differential identification," and is employed to meet two objections to differential association. First, some critics have interpreted "association" in Sutherland's writings as synonymous with "contact," which seems to have dismayed him. ${ }^{123}$ Thus, the question may be asked, why prison guards and wardens do not become confirmed criminals. Cressey has also said that differential association clearly implies differential identification as a congruent aspect. Second, it is held that differential association cannot account for crimes due to accident, transitory situations, and personality-the last assuming that the major aspects of personality determining crime are fixed in childhood. But a conception of personality as the organization of one's roles, including those that develop largely in adulthood (class and occupation, for example) meets this objection. In this conception, criminality itself is a component of personality. Thus, the theory explaining criminality can be the theory explaining other components of personality. If differential association is reconceptualized into the terms of differential identification, the

${ }^{131}$ Glaser, Criminality Theories and Behavioral Images, 6r AM. J. Socrology 433 (1956).

${ }^{122}$ Sce also Foote, Identification as the Basis for a Theory of Motivation, I6 AM. Socrolocrcal Rev. 14 (1951); Shibutani, Reference Groups as Perspectives, 60 AM. J. Socrology 562 (1955). The study by Sykes \& Matza, supra note 113 , is another contribution to the present development.

123 Edwin H. Sutherland, Principles of Criminology 57 n. 25 (4th ed. 1947). 
"accidental" and the "transitory situation" may also be accounted for, with the exception, of course, of those events that are actually accidental.

Glaser's theory of differential identification is, in essence, as follows: a person pursues criminal behavior to the extent that he identifies himself with real or imaginary persons from whose perspective his criminal behavior seems acceptable. It is a major contribution to a general theory of criminality.

\section{VII}

Until 1955, textbooks in criminology were two books within two covers. The first dealt with criminology - that is, theories of causation that were presented until 1939 in a mismash of eclecticism. The second book dealt with penology, now referred to as "corrections." The two books were usually separated by several inadequate chapters on the police and the courts and also by few or more mutually-exclusive theories and conclusions. The fifth edition of Sutherland's Principles of Criminology, revised by Donald R. Cressey, was the first time that an integration of criminology and corrections was attempted, so as to present a viewpoint consistent throughout the two parts of the book. This was a result of the attempt to develop a generalizing theory in sociological terms. The chapter on "The Prison Community" is one of the most important contributions of Cressey to that volume.

The emphasis on research and the attempt to develop an integrative theory have given a tremendous impetus to sociological research in corrections, a term that includes what was until recently "penology," as well as probation, parole, "treatment," prevention, and any other community endeavor having to do with crime. It must suffice to state here that the recent research in the field of corrections has both assumed and demonstrated, within any correctional institution, the existence of a social system with a certain cultural content, having relations with other social systems in the society as a whole, and to which the convicted offender must adjust and within which he can have some kind of function and on which he can have a more or less limited effect. The important concepts are those that are also important in current criminology: subculture, social organization, role, communication, motivation, self-conception, and the like. One series of investigations has studied the prison from the viewpoint of social control, examined the administrative problems of a treatment-oriented prison and the problems of the professional personnel and guards in such a prison, conceived the prison as a social system, conceived it as a system of power, conceived it as a system of social roles, and analyzed the organizational problems faced by departments of probation and parole when they attempt to professionalize the staff. ${ }^{124}$

124 Soon to be published, these papers will have an enormous influence, not only in the field of criminology and correction, but in the general field of sociological theory.

The papers are: Cloward, Social Control in the Prison; Cressey, The Professional and the Guard in the Treatment-Oriented Prison; Organizational Limitations on Administration of Treatment in the Treatment-Oriented Prison; Grosser, The Prison as a Social System; McClecry, Communication and Power in a Prison Community; Sykes \& Messinger, The Inmate Social System; Ohlin \& Pappenfort, Social Change and Organizational Succession. Each of these studies has an extensive bibliography.

Some books that conceive the prison as a community and a social system, and which fall within this 


\section{VIII}

The previous discussion has revealed several instances of sociological imperialism. It has been implied that biology, under the guise of constitutional psychology, should abandon criminology, at least until it is able to adduce biological (or genetic) evidence to support its speculations, instead of the behavioral evidence upon which it has depended until now. Clinical psychology has also been invited to abandon the field on two grounds. First, it has been maintained that most cases of mental retardation (the garden-variety) are explicable in social psychological terms. Second, "personal" factors have been shown to be biological, or neurological, or social-psychological, or statistical. Jurisprudence has been impliedly invited to re-examine its philosophy of administrative, civil, and criminal proceedings so as to align them with the reality of crime. Sociologists have been admonished to abandon their paste-pot-and-scissors eclecticism and to try to develop a generalizing theory that is in keeping with the philosophy of science. Perhaps the theory of differential association (and differential identification) has been so vigorously attacked by so many sociologists because it revealed them to be just about anything but sociologists.

The last trend to be considered in this critique attacks the stronghold of that holy of holies, psychiatry, which is perhaps the last remnant of the medieval absolutist control over the destiny of the individual. This trend establishes the sociological and social-psychological claim for the explanation of the sexual offender and the so-called compulsive criminal, as exemplified in crimes of passion, kleptomania, incendiarism, and the like. In two studies, Sutherland called into question the assumptions on which psychiatry had justified the enactment of sexual psychopath laws in some twenty-two states in this country. ${ }^{125}$ A number of state commissions on which sociologists served, as directors, or consultants, or members, were likewise critical of the attempts of psychiatry to establish and maintain exclusive jurisdiction over all types of sexual offenders, from the innocuous voyeurs and exhibitionists to

trend of research, are: Donald Clemmer, The Prison Community (rev. ed. i958); Lloyd W. McCorkle, Albert Elias, \& F. Lovell Bixby, The Highfields Story (i958); Lloyd E. OhLin, Sociology and the Field of Corrections (1956); George Rusche \& Otto Kirchremer, Punishment and Social Structure (x939); Richard McCleert, The Strange Journey (1953); Policy Change in Prison MANaGEMENT (1957).

Some relevant articles are: Adamson \& Dunham, Clinical Treatment of Male Delinquents: A Case Study in Effort and Result, 21 Am. Socrologrcal Rev. 312 (1956); Cressey, The State of Criminal Statistics, 3 N.P.P.A.J. 230 (1957); Rehabilitation Theory and Reality, Cal. Youth Authority Q. no. 3, p. 40 (I957); Cressey \& Krassowski, Inmate Organization and Anomie in American Prisons and Soviet Labor Camps, 5 Social Problems 217 (1958); Diana, Is Casework in Probation Necessary?, 34 Focus I (1955); Dunham \& Knauer, The Tuvenile Court in Its Relationship to Adult Criminality, 32 Social Forces 290 (1954); England, What Is Responsible for Satisfactory Probation and Post-Probation Outcome?, $47 \mathrm{~J}$. Crim. L., C. \& P.S. 444 (1956); Glaser, Testing Correctional Decisions, 45 J. Crim. L., C., \& P.S. 679 (1955); Grosser, The Role of Informal Inmate Groups in Change of Values, 5 CHrLden 25 (1958); Hartung \& Floch, A Social Psychological Analysis of Prison Riots, 47 J. Crim. L., C. \& P.S. 5I (1956); Hayner \& Ash, The Prisoner Community as a Social Group, 4 AM. Socrological Rev. 362 (I939); Ohlin, The Routinization of Correctional Change, 45 J. CRrM. L., C. \& P.S. 400 (1954); Vold, Does the Prison Reform?, 293 ANNals 42 (1954).

${ }^{125}$ Sutherland, The Sexual Psychopath Laws, 40 J. CRm. L. \& CRIMrnology 543 (1950), reprinted in Cohen, Lindesmith, \& Schuessler, op. cit. stupra note 15, at 185 ; The Diffision of Sexual Psychopath Laws, 56 AM. J. Sociology 142 (1950). 
the brutal assaults sometimes (rarely) committed during a rape-murder. ${ }^{120}$ As a result of his research, Bowman came to the conclusion that: ${ }^{127}$

It now appears that psychiatry has been oversold in its legal efforts to define the term sexual psychopath; to predict potentially dangerous sex offenders; and to obtain permanent cures through effective methods of treatment.

Floch, without meaning to be cynical, argues that the difference between acquittal on a plea of temporary insanity and conviction on some charge of assault, is very often no more than the difference between a defendant who can pay a psychiatrist's fee and a defendant who cannot. ${ }^{128}$

The most cogent statement of the claim that sexual offenders, the "temporarily insane," and the "compulsive" acts of kleptomania and incendiarism are motivated through the same social psychological processes as other acts, has been developed by Cressey. ${ }^{129}$ In a very complex article, employing the social psychological meanings of the concepts motivation, role-playing, and identification, Cressey shows that supposedly compulsive crimes have a motivational and developmental history; that they involve the use of symbolism (linguistic constructs); and that they, therefore, do not constitute exceptions to the theory of differential association and identification. One may add that an easy way to embarrass a psychiatrist or psychoanalyst who employs the term is to ask him to define a compulsive act and to distinguish logically between "compulsion" and "habit."130

One result of the criminological concern with the dynamics of human behavior is the beginning of a reappreciation of the rational quality of even the most routune and ordinary actions of our daily life.

It can be said that the sociological approach to criminology is today in a state of ferment.

${ }^{126}$ H. Warken Dunham, Crucial Issues in the Treatment and Control of Sexual Deviation in the Community (195i); Paul W. Tappan, The Habitual Sex Offender (r951); Ill. Comm'n on Sex Offenders, Report (i953); Final Report on California Sexual Deviation Research (1954).

${ }^{127}$ Bowman, Review of Sex Legislation and Control of Sex Offenders in the United States of America, in Final Report on California Sexual Deviation Research 20 (1954).

${ }^{128}$ Floch, The Concept of Temporary Insanity Viewed by a Criminologist, 45 J. Cum. L., C. \& P.S. 685 (1955).

${ }^{120}$ Cressey, The Differential Association Theory and Compulsive Crimes, 45 J. CRIM. L., C. \& P.S. 29 (1954). Some sociologists accept the concept of compulsive crimes openly. Reckless attempts to conceal it under the phrases "crime of the moment" and "eruptive behavior." Walter C. Reckless, The Crime Problem 73 (2d ed. 1955).

${ }^{130}$ Even Lundberg, Schrag, and Larsen find it both necessary and possible to genuflect before psychiatry, in their discussion of "Psychiatric Study of William Heirens." George A. Lundberc, Clarence C. Schrag, \& Otro N. Larsen, Sociology 340-44 (rev. ed. I958). 